\title{
PRODUCTION OF BIOGAS BASED ON HUMAN FESSES AS AN ALTERNATIVE ENERGY FOR REMOTE AREAS APPLICATION
}

\author{
IMAM SYOFI * , DEWI PUSPITA SARI \\ Study Program of Mechanical Engineering Education, Faculty of Teacher Training and Education, \\ Universitas Sriwijaya, Indralaya-30662, South Sumatera, Indonesia \\ *Corresponding author: imamsyofii@unsri.ac.id
}

(Received: 11 September 2021; Accepted: 10 October 2021; Published on-line: 1 March 2022)

\begin{abstract}
The utilise of biogas for remote areas is a problem because it is challenging to supply hydrogen. Hence a study of the utilisation of human fesses as biogas raw material for biogas production is proposed. Due to high investment costs to build miniature power plants, modified gasoline engines are used as mini power plants even though it is a laboratory scale. Based on results, human fesses can be used as raw material for biogas production. Performance engine using biogas derived from human fesses is $9 \%$ different from LPG. The maximum efficiency of the biogas system is $32 \%$, and that of the LPG is $41 \%$.
\end{abstract}

KEY WORDS: Biogas, human fesses, gasoline engine, power plant

\section{INTRODUCTION}

The increase in population is proportional to the energy consumed. In Indonesia, in 2025, it is predicted that the energy consumed will be 2.2 barrels of oil per day (BOPD) [1]. The Government of Indonesia, through Presidential Regulation (Peraturan Presiden) number 5 of 2006 concerning the National Energy Policy (Kebijakan Energi Nasional), seeks to meet energy needs is the composition sourced from new and renewable energy by more than $5 \%$ by 2025 [2]. Subsequently refined through the National Energy General Plan (Rencana Umum Energi Nasional) in 2017, the national energy composition by new and renewable energy of $23 \%$, petroleum of $25 \%$, natural gas of $22 \%$, and coal of $30 \%$ [1]. Furthermore, the preventive steps taken by the Government of Indonesia are the conversion of kerosene to liquefied petroleum gas (LPG) and liquefied natural gas (LNG).

The use of LPG and LNG as substitute energy sources needs to be reviewed. Since LPG and LNG have limited reserves and are non-renewable, this motivates many studied to find new alternative energy sources that are easy, inexpensive, and environmentally friendly. The alternative energy source of concern is biogas because the potential is large, methane content $(\mathrm{CH} 4)$ is high, and calorific value ranges from 4800 to $6.700 \mathrm{kcal} / \mathrm{m}^{3}$ [3]. Biogas is considered safer than LPG because it has a methane gas density of 55 lower than LPG [4]. Another advantage of biogas is that it has a research octane number (RON) of 130 higher than gasoline of 94, benzol of 98, LPG of 112, and compressed natural gas (CNG) of 120 [5]. The high RON of biogas produces lower gas emissions than gasoline, benzol, LPG, and CNG [6].

The Indonesian government target that in 2025 that biogas exploitation will reach $5.5 \mathrm{GW}$ (16.9\%) from a potential of $32.7 \mathrm{GW}$ [1], designated as a power plant. In refining the target, the Indonesian government will build a biogas installation with a household scale. Therefore, the use of biogas made from fesses as an alternative fuel becomes interesting to study. 
In Indonesia, there have been many studies that examine the use of biogas as alternative energy. Kholiq and Muharom (2012) [3] have examined the utilisation of human fesses as a biogas reactor with a capacity of $16 \mathrm{~m}^{3}$. It was concluded that to get methane gas $\left(\mathrm{CH}_{4}\right)$ with a content of $77 \%$, lighting lamps for biogas were needed at 0.23 hours $/ \mathrm{m}^{3}$ with a pressure of 45 $\mathrm{mmH}_{2} \mathrm{O}$ [3]. Haryati (2006) [7] utilised the livestock waste for producing biogas, where the optimum conditions for producing biogas are at temperatures of 32 to $35^{\circ} \mathrm{C}$ and $\mathrm{pH}$ between 6.8 to 8 [7]. Purnomo (2009) [8] conducts biogas purification using $\mathrm{H}_{2} \mathrm{~S}$, where the purified biogas is tested on a gasoline engine. Purnomo concluded the $\mathrm{H}_{2} \mathrm{O}$ absorption method using $\mathrm{H}_{2} \mathrm{~S}$ was successful, with $1.76 \mathrm{~g} \mathrm{H}_{2} \mathrm{O}$ /hours [8]. Elizabeth and Rusdiana (2011) [6] utilise biogas as a power plant fuel for remote areas. Biogas produces by plant waste, and livestock fesses and human fesses [6]. Feasibility study of biogas produced by plant waste, livestock fesses and human fesses as a power plant fuel is recommended to be applied in remote areas in Indonesia [6].

Biogas has become a special concern for both the Indonesian government and researchers. Studies of the characterisation of chemical kinetics and thermodynamics of biogas have been carried out $[9,10]$. Based on reports, the challenge in utilising large-scale biogas is the instability between production (supply) and consumption [11]. The solution is to add $\mathrm{H}_{2}$ to save fuel to anticipate instability [11]. The utilise of biogas for remote areas is a problem because it is difficult in supplying $\mathrm{H}_{2}$. Therefore, a study of the utilisation of human fesses as biogas raw material for biogas production is proposed. Due to high investment costs to build miniature power plants, even though it is a laboratory scale [12-14], modified gasoline engines are used as mini power plants.

\section{METHOD}

Biogas was produced from the process of decomposing organic matter by microorganisms in anaerobic (vacuum) conditions. The anaerobic processes break down organics matters by activating bacteria; these bacteria naturally contain organics material: fesses by animal or human and household organics waste [8].

Biogas production uses an anaerobic process consists of three stages: hydrolysis is the decomposition of complex organic matter into simple, structure changes in the polymers form to monomers; acidification, acidification of monomers component (simple sugars) created in the hydrolysis stage is food for bacteria; methanogenic, the process of developing methane gas, bacteria reduce sulphate and other sulphur components into hydrogen sulphide. The process production biogas (fermentation) can be seen in Fig. 1.

Fig. 1 describes the process of changing cellulose to gas. The bacteria in the anaerobic process are hydrolytic, fermentative bacteria, acidogenic bacteria, and methanogenic bacteria [8]. The hydrolytic bacteria function to break down organics matter into sugars and amino acids [6]. The fermentative bacteria convert sugars and amino acids into organics acid [8]. The acidogenic bacteria change organics acid to hydrogen, carbon dioxide and acetic acid [3]. The methanogenic bacteria transform hydrogen, carbon dioxide and acetic acid into methane [7]. 


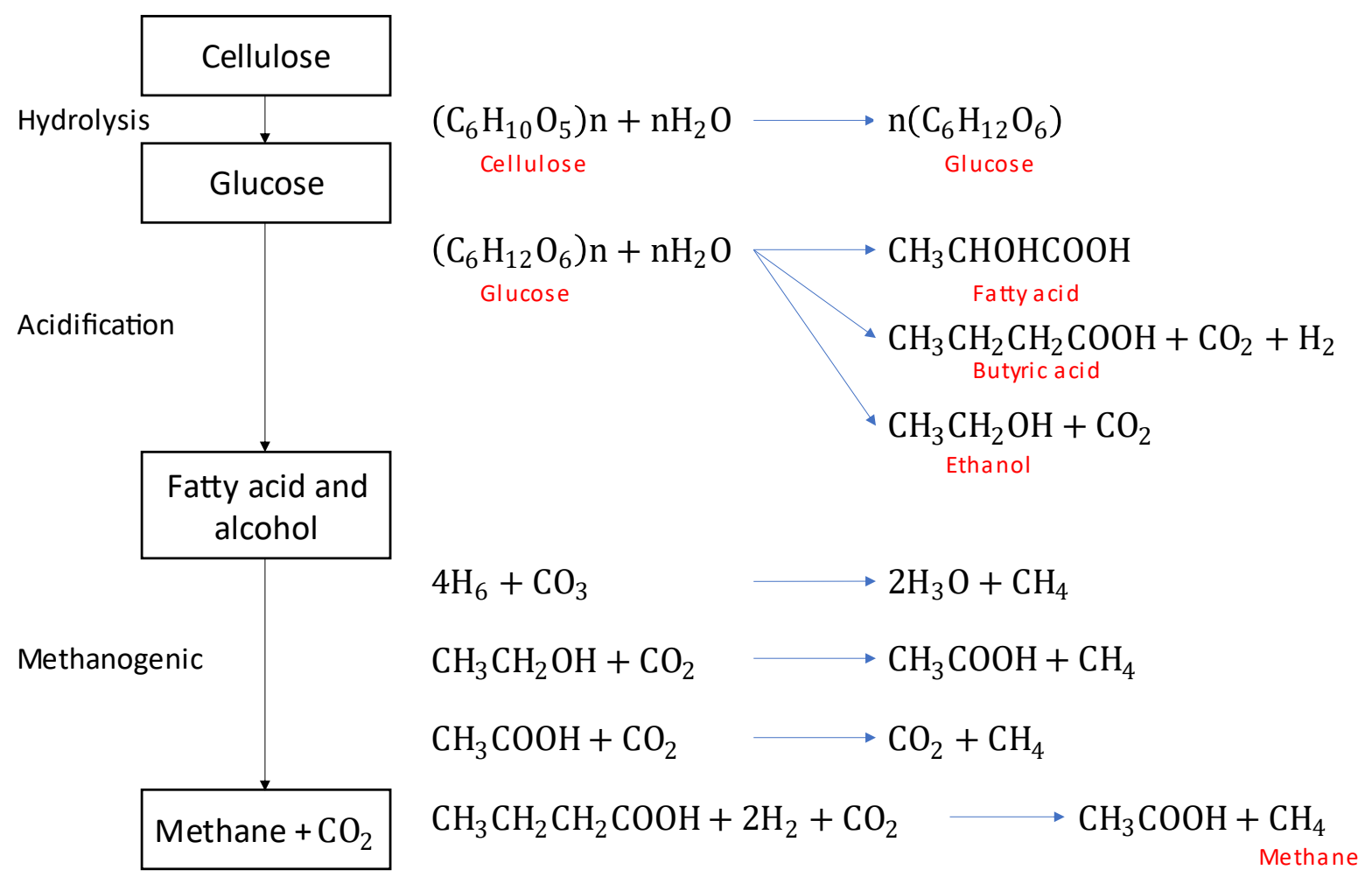

Fig. 1. Fermentation process [7]

The fesses are processed in a digester in the condition of anaerobic with temperature maintained at $35^{\circ} \mathrm{C}$. The first production is $\mathrm{CO}_{2}$ gas on days 1 to 8 . The methane gas and $\mathrm{CO}_{2}$ gas are produced on the 10 to 14 . For more than 14 days, methane gas without $\mathrm{CO}_{2}$ gas is produced. The methane gas produced over 14 days was used. However, gas production depends on the composition of the raw material used. For this case, the results obtained are like this.

The digester is connected to the gasoline engine using a pipe, gas carburettor, gas regulator, and valve (Fig. 2). This case compares biogas with LPG. The valve opening for the biogas system is $180^{\circ}$. Gas pressure conditions of $180^{\circ}$ for biogas are equivalent to $40^{\circ}$ for LPG systems.

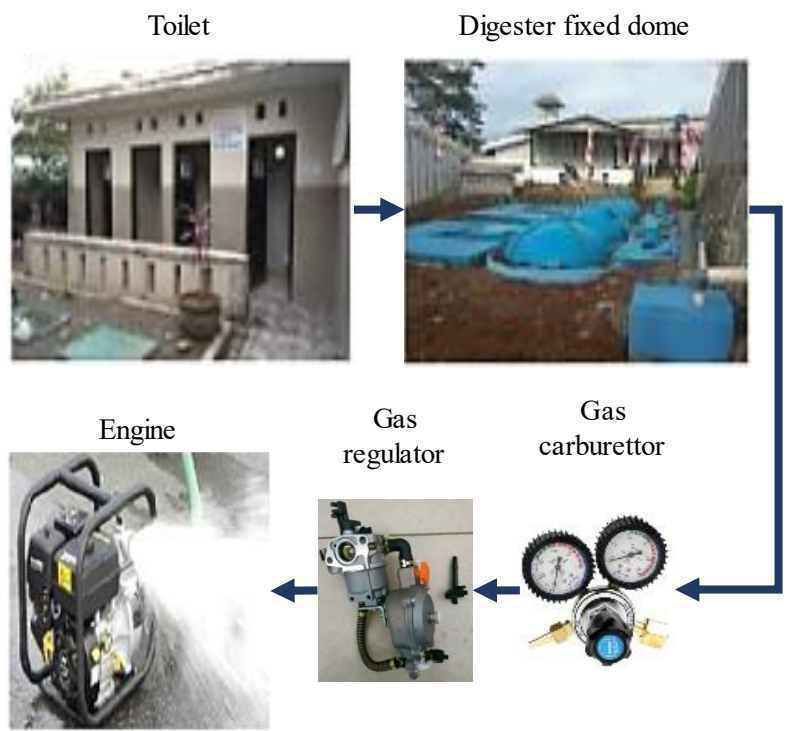

Fig. 2. Biogas system installation 


\section{RESULTS AND DISCUSSION}

Based on Fig. 3, as the engine speed increases, the water flow increases. The highest water discharge produced by a water pump using biogas fuel is $0.118 \mathrm{~m}^{3} / \mathrm{s}$ at $6600 \mathrm{rpm}$, while LPG produced was $0.150 \mathrm{~m}^{3} / \mathrm{s}$. From the results, the discharge of LPG fuel water is higher than biogas because LPG gas pressure into the combustion chamber is more constant than biogas. Based on Fig. 4, the increased discharge produced by the water pump, the greater the waterpower $\left(\mathrm{P}_{\mathrm{w}}\right)$ produced. The maximum waterpower produced by the water pump using LPG fuel is $1.6 \mathrm{~kW}$ at $6600 \mathrm{rpm}$, and biogas is $1.26 \mathrm{~kW}$.

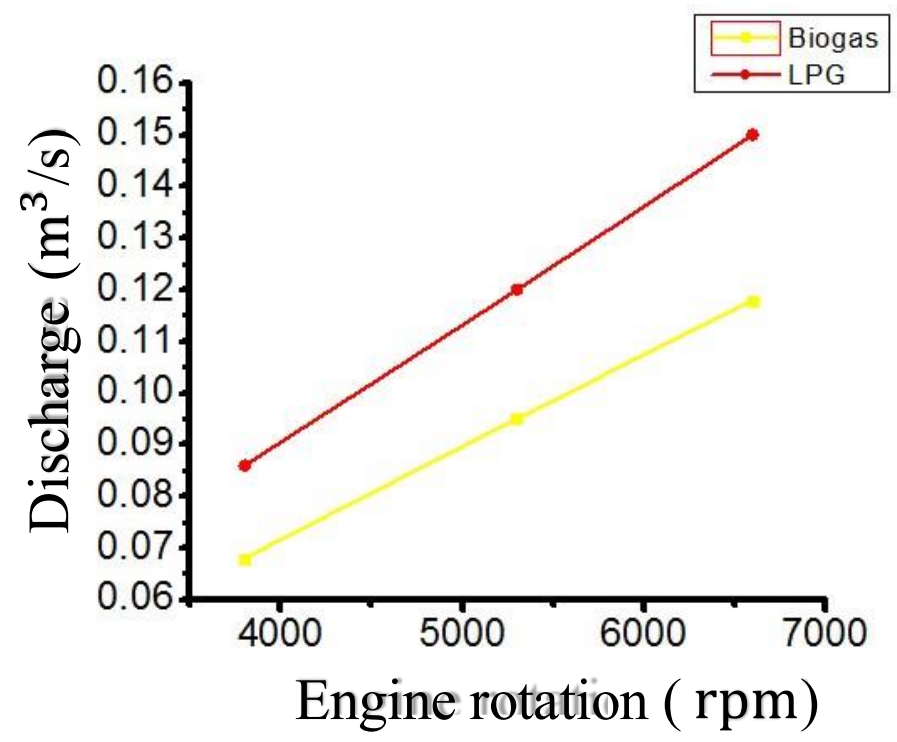

Fig. 3. Relation of discharge into engine rotation

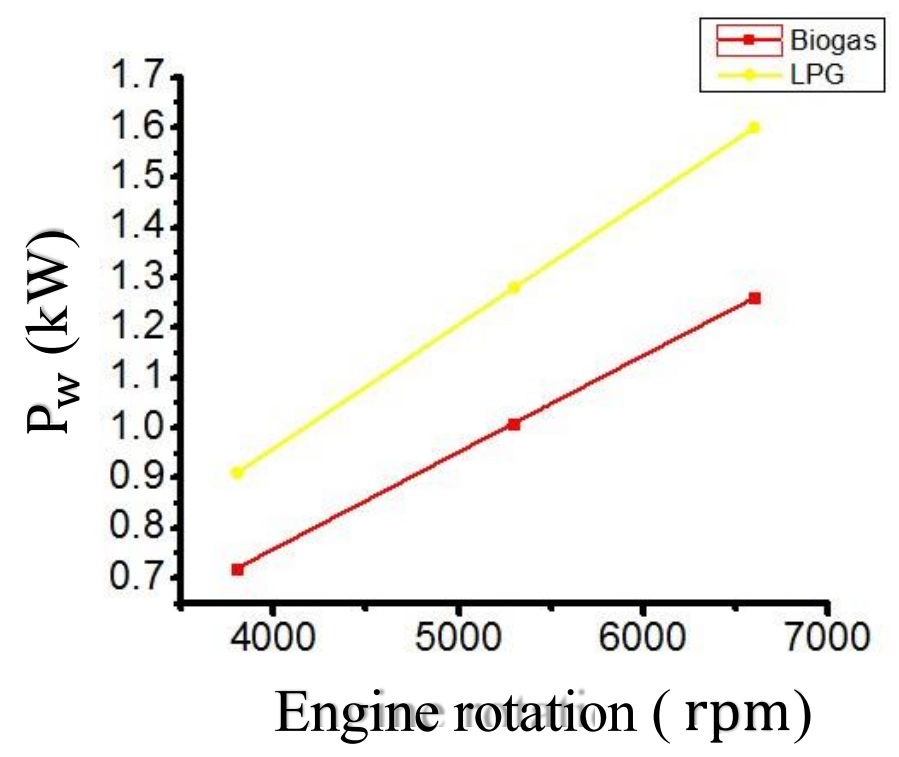

Fig. 4. Relation of $\mathrm{P}_{\mathrm{w}}$ into engine rotation

From Fig. 5, the maximum efficiency of the biogas system is $32 \%$, and that of the LPG is $41 \%$. From the results, biogas is an appropriate alternative as a fuel source and being environmentally friendly because the combustion is close to perfect and does not smoke. Biogas combustion also does not produce odor (even if it comes from faeces), consequences, and is safe to use for the household. 


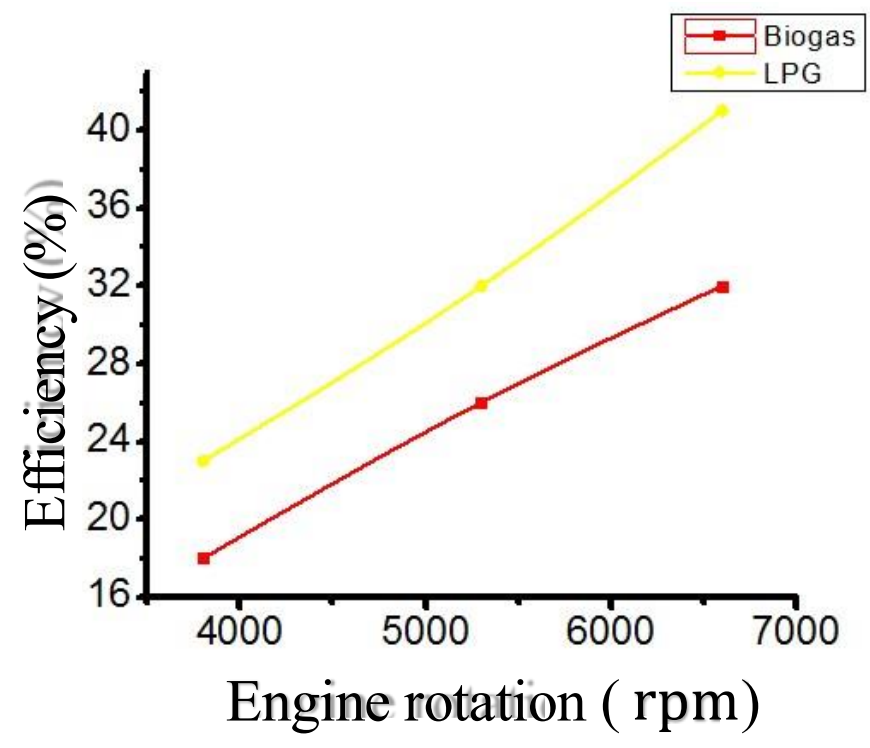

Fig. 5. Relation of efficiency into engine rotation

\section{CONCLUSION}

Based on results, human fesses can be used as raw material for biogas production. Performance engine using biogas derived from human fesses is $9 \%$ different from LPG. The maximum efficiency of the biogas system is $32 \%$, and that of the LPG is $41 \%$.

\section{REFERENCES}

[1] KESDM, Rencana Umum Energi Nasional, Jakarta, 2017.

[2] Peraturan Presiden Nomor 5 Tahun 2006 Tentang Kebijakan Energi Nasional (KEN), (2006).

[3] I. Kholiq, M. Muharom, ANALISIS PERENCANAAN REAKTOR BIOGAS KAP 16 m3 DENGAN PEMANFAATAN KOTORAN MANUSIA, J. Eng. Manag. Ind. Syst. 3 (2015).

[4] M. Suyitno, N. Dharmanto, Teknologi Biogas, (2010).

[5] M. Setiyo, B.C. Purnomo, Investigasi Penurunan Daya Mobil Berbahan Bakar Lpg melalui Pengukuran Efisiensi Volumetrik, Pros. Semnastek. 1 (2014).

[6] R. Elizabeth, S. Rusdiana, Efektivitas Pemanfaatan Biogas Sebagai Sumber Bahan Bakar Dalam Mengatasi Biaya Ekonomi Rumah Tangga di Perdesaan, in: Pros. Semin. Nas. Era Baru Pembang. Pertan. Strateg. Mengatasi Masal. Pangan, Bioenergi Dan Perubahan Iklim. Pus. Sos. Ekon. Dan Kebijak. Pertanian. Bogor P, 2011: pp. 220-234.

[7] T. Haryati, Biogas: Limbah peternakan yang menjadi sumber energi alternatif, J. War. 16 (2006) 160-169.

[8] J. Purnomo, Rancang bangun pembangkit listrik tenaga biogas, (2009).

[9] M. Fischer, X. Jiang, An investigation of the chemical kinetics of biogas combustion, Fuel. 150 (2015) 711-720.

[10] L. Janke, A. Leite, M. Nikolausz, T. Schmidt, J. Liebetrau, M. Nelles, W. Stinner, Biogas production from sugarcane waste: assessment on kinetic challenges for process designing, Int. J. Mol. Sci. 16 (2015) 20685-20703.

[11] Y. Qian, S. Sun, D. Ju, X. Shan, X. Lu, Review of the state-of-the-art of biogas combustion mechanisms and applications in internal combustion engines, Renew. Sustain. Energy Rev. 69 (2017) 50-58.

[12] A.F. Hery, Z. Septiropa, S. Riansyah, F. Romadhi, Pemanfaatan Biogas/Landfillgas sebagai bahan bakar Mesin Bensin 1 Silinder 4 Langkah, J. Tek. Ind. 12 (2012) 162-168.

[13] D. Wulandani, Rancang Bangun Konverter Biogas untuk Motor Bensin Silinder Tunggal, J. Keteknikan Pertan. 2 (2015).

[14] J.P.G. Montoya, A.A. Amell, D.B. Olsen, G.J.A. Diaz, Strategies to improve the performance of 
a spark ignition engine using fuel blends of biogas with natural gas, propane and hydrogen, Int. J. Hydrogen Energy. 43 (2018) 21592-21602. 